\title{
Perbedaan Skala Nyeri Antara Blok Pleksus Servikalis Superfisialis dan Fentanil Intavena Sebagai Analgesi Pascaoperasi Mastoidektomi
}

\author{
Stephanus Kaligis, Ardana Tri Arianto, M. Husni Thamrin \\ Departemen Anestesiologi dan Terapi Intensif Fakultas Kedokteran Universitas Sebelas Maret/ \\ Rumah Sakit Umum Daerah Dr. Moewardi, Surakarta
}

\begin{abstract}
Abstrak
Penelitian tentang penggunaan blok pleksus servikalis superfisialis sebagai analgetik pascaoperasi mastoidektomi masih sangat terbatas baik di Indonesia maupun luar negeri. Tujuan penelitian mengetahui efektivitas blok pleksus servikalis superfisialis sebagai analgetik pascaoperasi mastoidektomi. Penelitian ini berdisain uji klinik acak tersamar tunggal pada 30 pasien yang dilakukan operasi mastoidektomi dan memenuhi kriteria inklusi di Rumah Sakit Dr. Moewardi Surakarta periode Oktober 2017-Februari 2018. Sampel dibagi menjadi 3 kelompok, yaitu kelompok fentanil intravena, blok pleksus cervicalis superfisialis dengan levobupivakain, dan blok pleksus cervicalis superfisialis dengan salin. Semua pasien mendapatkan perlakuan anestesi umum sesuai standar dan dinilai skala nyeri berkala pascaoperasi. Selain itu, juga dinilai efek mual-muntah pascaoperasi, kebutuhan opioid selama operasi, dan efek samping tindakan blok. Skala nyeri pascaoperasi mulai jam ke-2 sampai ke-24 pada kelompok fentanil intravena (nyeri ringan 80-90\%) dan levobupivakain (nyeri ringan 90-100\%) lebih rendah dibanding dengan kelompok salin (nyeri ringan 10-50\%; nyeri sedang 50-70\%) ( $\mathrm{p}<0,05)$. Pada kelompok salin bahkan terjadi nyeri berat sebanyak $40 \%$ pada jam ke-2. Skor PONV pada kelompok fentanil, levobupivakain, dan salin mayoritas mual ringan (60\%; 40\%; dan 50\%). Tidak ada komplikasi yan g terjadi terkait blok pleksus servikalis superfisialis. Simpulan, tidak ada perbedaan skala nyeri yang bermakna antara blok pleksus servikalis superfisialis levobupivakain dan fentanil intravena pascaoperasi mastoidektomi.
\end{abstract}

Kata kunci: Blok pleksus servikalis superfisialis, fentanil, levobupivakain, mastoidektomi

\section{Difference in Pain Scale between Levobupivacaine Superficial Cervical Plexus Block and Intravenous Fentanyl for Post-Post-Mastoidectomy Pain}

\begin{abstract}
Research on the use of superficial cervical plexus block as an analgesic after mastoidectomy is still very limited both in Indonesia and abroad. The purpose of this study was to determine the efficacy of superficial cervical plexus block as an analgesics for post-post-mastoidectomy pain. This was a single blinded randomized clinical trial study performed on 30 patients underwent mastoidectomy who met the inclusion criteria in Dr. Moewardi General Hospital Surakarta October 2017-February 2018. Subjects were divided into 3 groups: levobupivacaine block, saline block, and intravenous fentanyl groups. All patients received standard general anesthesia treatment and were evaluated periodically for the post-operative pain scale. The post-operative effects post-including nausea-vomiting, opioid need during surgery, and side effects of the block were also assessed. The pos-toperative pain scales 2 to 24 hours after surgery in the intravenous fentanyl (mild pain 80-90\%) and levobupivacaine group (mild pain 90-100\%) were lower than those in the saline group (mild pain 10-50\%, moderate pain 50-70\%) $(\mathrm{p}<0.05)$. In the saline group, severe pain was even identified 2 hours after the surgery in as high as $40 \%$ of the subjects. Comparison of the pain scale between fentanyl and levobupivacaine groups from 2 to 24 hours after surgery did not show any significant difference. PONV scores in the fentanyl, levobupivacaine, and saline groups reflected mild nausea (60\%, $40 \%$, and $50 \%$ respectively). No complication occurred in superficial cervical plexus block application. In conclusion, there is no significant difference in pain scale between the superficial cervical plexus block using levobupivacaine and intravenous fentanyl in terms of post-post-mastoidectomy pain.
\end{abstract}

Key words: Fentanyl, levobupivacaine, mastoidectomy, superficial cervical plexus block

Korespondensi: Stephanus Andy Prakasa Kaligis, dr., SpAn, Departemen Anestesiologi dan Terapi Intensif Fakultas Kedokteran Universitas Sebelas Maret/Rumah Sakit Umum Daerah Dr. Moewardi, Jl. Kol. Sutarto no. 132, Surakarta, 57126, Tlpn. 0271-639262, Email stepzndy@gmail.com 


\section{Pendahuluan}

Nyeri yang tidak tertangani dengan baik memberikan dampak seperti peningkatan hormon stres, resistensi terhadap insulin, dan peningkatan katabolisme. ${ }^{1}$ Nyeri pascaoperasi mastoidektomi merupakan nyeri akut dengan intensitas sedang-berat. ${ }^{2}$ Hasil penelitian oleh Nemati dkk. ${ }^{3}$ dari 155 pasien yang pernah menjalani operasi mastoidektomi didapatkan 50 kasus (32\%) nyeri kronik dengan faktor risiko yang signifikan adalah nyeri akut pascaoperasi yang tidak tertangani dengan baik.

Fentanil telah digunakan secara luas sebagai analgetik pascaoperasi baik melalui jalur intravena, epidural, maupun teknik lain. ${ }^{4}$ Fentanil intravena memiliki efektivitas yang sebanding dengan morfin intravena dengan keunggulan onset cepat, durasi singkat, dan tidak menimbulkan pelepasan histamin sehingga menjaga kestabilan hemodinamik. Dosis cepat dan durasi singkat mempermudah untuk titrasi dosis sesuai kebutuhan pasien. ${ }^{5}$

Angka kejadian postoperative nausea and vomiting (PONV) pascaoperasi telinga tengah cukup tinggi karena telinga tengah berhubungan dengan organ keseimbangan. Teknik anestesi selama dilakukan operasi dan penggunaan opioid dengan dosis tinggi juga berperan meningkatkan kejadian PONV. ${ }^{6}$

Blok pleksus servikalis superfisialis dapat memberikan analgesia sensorik untuk area postauricular dari scalp, eksternal pinna, area aurikularis posterior, bagian anterior leher, dan area supraklavikular. Blok pleksus servikalis superfisialis yang bilateral dapat memberikan analgesi untuk pembedahan pada bagian anterior leher seperti pembedahan tiroid..$^{7-9}$ Data mengenai efektivitas blok ini untuk operasi mastoidektomi belum jelas.

Tujuan penelitian ini adalah mengetahui efektivitas blok pleksus servikalis superfisialis sebagaianalgetik pascaoperasi mastoidektomi.

\section{Subjek dan Metode}

Penelitian dengan desain uji klinis acak tersamar tunggal ini dilaksanakan di Rumah
Sakit Dr. Moewardi Surakarta dengan mengumpulkan data pasien sejak Oktober 2017-Februari 2018. Kriteria inklusi adalah pasien yang berusia 10-65 tahun, menjalani operasi mastoidektomi, dan status fisik ASA 1-2. Pasien dieksklusikan bila tidak mampu menggunakan skala nyeri numerical rating scale (NRS), terdapat kontraindikasi absolut anestesi regional, riwayat penggunaan obat antinyeri dalam 24 jam terakhir, dan riwayat nyeri kronik. Kriteria putus uji, yaitu bila terjadi perubahan tindakan dari operator, timbul reaksi hipersensitivitas, dan juga penambahan obat antinyeri oleh operator.

Pengumpulan sampel dilakukan setelah mendapatkan surat kelaikan etik dari Komisi Etik Rumah Sakit dr. Moewardi dan informed consent tertulis dari pasien. Sebanyak 30 pasien yang menjalani operasi mastoidektomi dibagi secara acak ke dalam tiga kelompok, yaitu fentanil intravena (kelompok F), blok levobupivakain (kelompok L), dan blok saline (kelompok S) masing-masing sebanyak 10 pasien.

Operasi dilakukan dengan teknik anestesi umum secara standar. Premedikasi dengan metoklopramid $10 \mathrm{mg}$ dan fentanil $2 \mathrm{mcg} /$ $\mathrm{kg}$ intravena. Induksi dengan menggunakan propofol $2 \mathrm{mg} / \mathrm{kgBB}$ dan pelumpuh otot atrakurium $0,5 \mathrm{mg} / \mathrm{kgBB}$. Setelah terintubasi, anestesi dipertahankan dengan sevofluran 2 vol\% dan kombinasi oksigen-air bar dengan fraksi oksigen 50\%. Bolus fentanil 25-50 mcg diberikan bila terjadi peningkatan denyut jantung atau tekanan darah lebih dari 20\% nilai basal. Pelumpuh otot atrakurium $10 \mathrm{mg}$ tiap 30 menit.

Pasien yang terpilih dalam kelompok L dilakukan blok pleksus servikalis superfisialis levobupivakain $0,375 \%$ oleh tim anestesi yang bertugas di kamar operasi. Blok dilakukan setelah terintubasi. Titik insersi adalah titik tengah dari garis yang menghubungkan prosesus mastoideus dan klavikula pada batas posterior ototsternokleidomastoideus. Setelah tindakan asepsis-antisepsis, levobupivakain $0,375 \%$ diinjeksikan dengan cara subkutan sebanyak $5 \mathrm{~mL}$ pada titik insersi, kemudian diarahkan ke kranial diinfiltrasi sebanyak 5 
$\mathrm{mL}$. Prosedur menggunakan syringe $10 \mathrm{~mL}$ dan jarum no. 23G. Pasien dalam kelompok S dilakukan tindakan serupa dengan $\mathrm{NaCl}$ 0,9\% sebagai agen untuk blok.

Pasien dalam kelompok $\mathrm{F}$ mendapatkan perlakuan anestesi yang sama tanpa blok pleksus servikalis superfisialis. Pemberian analgetik fentanil dimulai setelah pasien tiba di ruang pemulihan. Fentanil dilarutkan dalam cairan infus $\mathrm{NaCl}$ 0,9\% $500 \mathrm{~mL}$ dengan dosis $0,5 \mathrm{mcg} / \mathrm{kgBB} / \mathrm{jam}$ menggunakan infus pump. Durasi terapi selama 24 jam.

Selama operasi pasien diawasi tekanan darah, denyut jantung, durasi operasi, dan jumlah opioid yang diberikan. Semua pasien diberikan parasetamol $20 \mathrm{mg} / \mathrm{kgBB}$ tiap 8 jam dengan dosis pertama diberikan 30 menit sebelum operasi berakhir. Pasien dinilai skala NRS pada jam ke-2, jam ke-6, jam ke-12, dan jam ke-24. Bila skala nyeri lebih dari 4 maka diberikan ketorolak $30 \mathrm{mg}$ intravena dan bila lebih dari tujuh, diberikan fentanil 25-50 mcg intravena sebagai analgetik penyelamat.

Penilaian skala PONV dengan nilai 1: tidak mual; 2: mual ringan; 3: mual hebat; dan 4: muntah. PONV berat dinyatakan dengan nilai 3-4, sedangkan PONV ringan dengan nilai 1-2. Jika terjadi PONV berat maka diberikan ondansetron $4 \mathrm{mg}$, dapat diulang tiap 8 jam. Kelompok blok pleksus servikalis superfisialis baik dengan levobupivakain $0,375 \%$ maupun $\mathrm{NaCl}$ 0,9\% dinilai hematom, infeksi, nyeri di tempat suntikan, sindrom Horner, dan paresis nervus frenikus unilateral.

Data yang diperoleh kemudian dianalisis dengan program komputer statistical product and servise solution (SPSS) for windows versi 17.0. Variabel data demografi dicari nilai reratanya dan perbandingan variabel pada tiap-tiap kelompok diuji dengan Uji Kruskal Wallis untuk data nominal dan juga ordinal, sedangkan untuk data numerik menggunakan uji one-way ANOVA. Variabel data perbedaan tingkat nyeri tiap-tiap kelompok diuji dengan one-way ANOVA bila data terdistribusi normal atau dengan Uji Kruskal Wallis jika data terdistribusi tidak normal. Batas kemaknaan yang diambil adalah $\mathrm{p}<0,05$ dengan interval kepercayaan 95\%.

\section{Hasil}

Tabel 1 menjelaskan bahwa pada kelompok fentanil dan levobupivakain mayoritas pasien perempuan, sedangkan pada kelompok saline mayoritas laki-laki. Nilai $\mathrm{p}=0,035(\mathrm{p}<0,05)$ yang berarti bahwa terdapat perbedaan yang signifikan karakteristik responden berdasar atas jenis kelamin.

Karakteristik responden berdasar atas usia, body mass index (BMI), status fisik ASA, riwayat hipertensi, diabetes, merokok, diagnosis, jenis tindakan operator, lama operasi, dan penggunaan fentanil selama operasi tidak berbeda bermakna antara kelompok fentanil, levobupivakain atas Tabel 2 diketahui bahwa skala nyeri 2 jam pascaoperasi pada kelompok fentanil dan levobupivakain mayoritas pasien nyeri ringan, sedangkan pada kelompok saline mayoritas pasien nyeri sedang $(\mathrm{p}=0,000$; $\mathrm{p}<0,05$ ).

Skala nyeri 6 jam, 12 jam, dan 24 jam pascaoperasi pada kelompok fentanil dan levobupivakain mayoritas juga dengan nyeri ringan dibanding dengan kelompok saline mayoritas pasien dengan nyeri sedang dengan $\mathrm{p}<0,05$ yang berarti terdapat perbedaan yang signifikan tingkat nyeri pasien pada 6 jam, 12 jam, dan 24 jam pascaoperasi. Kelompok fentanil intravena dan kelompok levobupivakain memiliki efektivitas yang lebih

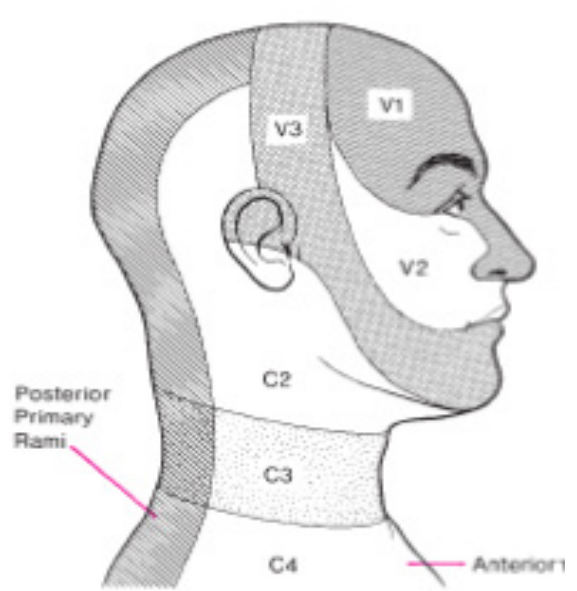

Gambar 1 Dermatom Sensorik dari Blok Pleksus Cervicalis Superfisialis (C2-C4)

Dikutip dari: Suresh S 
baik dibanding dengan kelompok saline.

Berdasar atas Tabel 3 tidak terdapat perbedaan skala nyeri yang signifikan antara blok pleksus servikalis superfisialis levobupivakain dan fentanil intravena pada 2 jam $(p=0,542), 6$ jam $(p=0,146), 12$ jam

Tabel 1 Karateristik Dasar Subjek Penelitian

\begin{tabular}{|c|c|c|c|c|c|}
\hline \multirow{2}{*}{ Karaktersitik } & \multicolumn{3}{|c|}{ Kelompok } & \multirow{2}{*}{ Total } & \multirow{2}{*}{$\mathbf{p}$} \\
\hline & Fentanil & Levobupivakain & Saline & & \\
\hline Jenis kelamin ${ }^{\mathrm{a}}$ & & & & & 0,035 \\
\hline Perempuan & 7 & 7 & 2 & 16 & \\
\hline Laki-laki & 3 & 3 & 8 & 14 & \\
\hline$U \operatorname{sia}^{c}$ & $41,5 \pm 14,2$ & $43,6 \pm 11,8$ & $28,9 \pm 15,5$ & $38,0 \pm 15,0$ & 0,054 \\
\hline $\mathrm{BMI}^{\mathrm{b}}$ & & & & & 0,735 \\
\hline Normal & 8 & 9 & 9 & 26 & \\
\hline Overweight & 1 & 1 & 0 & 2 & \\
\hline Obes 1 & 0 & 0 & 1 & 1 & \\
\hline Obes 2 & 1 & 0 & 0 & 1 & \\
\hline $\mathrm{ASA}^{\mathrm{a}}$ & & & & & 0,186 \\
\hline I & 2 & 0 & 3 & 5 & \\
\hline II & 8 & 10 & 7 & 25 & \\
\hline $\mathrm{HT}^{\mathrm{a}}$ & & & & & 0,335 \\
\hline Negatif & 10 & 9 & 10 & 29 & \\
\hline Positif & 0 & 1 & 0 & 1 & \\
\hline $\mathrm{DM}^{\mathrm{a}}$ & & & & & 0,585 \\
\hline Negatif & 9 & 10 & 9 & 28 & \\
\hline Positif & 1 & 0 & 1 & 2 & \\
\hline Merokok $^{\mathrm{a}}$ & & & & & 0,843 \\
\hline Ya & 2 & 3 & 3 & 8 & \\
\hline Tidak & 8 & 7 & 7 & 22 & \\
\hline Riwayat motion sickness ${ }^{a}$ & & & & & 0,843 \\
\hline Ya & 8 & 7 & 7 & 22 & \\
\hline Tidak & 2 & 3 & 3 & 8 & \\
\hline Diagnosis $^{\mathrm{a}}$ & & & & & 0,335 \\
\hline OMSK & 10 & 10 & 9 & 29 & \\
\hline Osteoma & 0 & 0 & 1 & 1 & \\
\hline Tindakan $^{\mathrm{a}}$ & & & & & 0,303 \\
\hline CWD & 1 & 4 & 3 & 8 & \\
\hline CWU & 9 & 6 & 7 & 22 & \\
\hline Lama operasi $^{c}$ & $223,0 \pm 32,7$ & $209,5 \pm 59,1$ & $216,5 \pm 61,1$ & $216,3 \pm 51,1$ & 0,849 \\
\hline Fentanyl durante $^{\mathrm{b}}$ & $244,0 \pm 37,1$ & $229,5 \pm 41,0$ & $244,0 \pm 58,0$ & $239,2 \pm 45,2$ & 0,076 \\
\hline
\end{tabular}

Keterangan: a. Uji chi square (skala data nominal)

b. Uji Kruskal Wallis (skala data ordinal atau numerik distribusi tidak normal)

c. Uji ANOVA (skala numerik distribusi normal) 
Tabel 2 Perbedaan Skala Nyeri antara Blok Pleksus Servikalis Superfisialis Levobupivakain dan Fentanil Intravena Pascaoperasi Mastoidektomi dan Saline

\begin{tabular}{|c|c|c|c|c|c|}
\hline \multirow{2}{*}{ Nyeri } & \multicolumn{3}{|c|}{ Kelompok } & \multirow{2}{*}{ Total } & \multirow{2}{*}{$\mathbf{p}$} \\
\hline & Fentanil & Levobupivakain & Saline & & \\
\hline NRS_2 & & & & & 0,000 \\
\hline Nyeri ringan & 8 & 9 & 1 & 18 & \\
\hline Nyeri sedang & 2 & 1 & 5 & 8 & \\
\hline Nyeri berat & 0 & 0 & 4 & 4 & \\
\hline NRS_6 & & & & & 0,000 \\
\hline Nyeri ringan & 8 & 10 & 2 & 20 & \\
\hline Nyeri sedang & 2 & 0 & 7 & 9 & \\
\hline Nyeri berat & 0 & 0 & 1 & 1 & \\
\hline NRS_12 & & & & & 0,010 \\
\hline Nyeri ringan & 8 & 10 & 4 & 22 & \\
\hline Nyeri sedang & 2 & 0 & 6 & 8 & \\
\hline Nyeri berat & 0 & 0 & 0 & 0 & \\
\hline NRS_24 & & & & & 0,015 \\
\hline Nyeri ringan & 9 & 10 & 5 & 24 & \\
\hline Nyeri sedang & 1 & 0 & 5 & 6 & \\
\hline Nyeri berat & 0 & 0 & 0 & 0 & \\
\hline
\end{tabular}

Keterangan: Uji Kruskal Wallis

$(\mathrm{p}=0,146)$, dan 24 jam $(\mathrm{p}=0,317)$ pascaoperasi dengan nilai $\mathrm{p}>0,05$.

Berdasar atas tabel 4 diketahui PONV pada kelompok fentanil mayoritas pasien dengan mual ringan, pada kelompok levobupivakain mayoritas pasien dengan tidak mual dan mual ringan, dan pada kelompok saline mayoritas pasien juga dengan mual ringan. Nilai $p=0,180(p>0,05)$ yang berarti bahwa tidak terdapat perbedaan yang signifikan skor PONV. Kelompok fentanil memiliki kejadian muntah yang lebih banyak dibanding dengan kelompok yang lain.

Berdasar atas Tabel 5, dari 20 tindakan blok pleksus servikalis superfisialis tidak didapatkan efek samping seperti infeksi, hematom, nyeri di tempat penusukan, sindrom horner, maupun paresis nervus frenikus unilateral.

\section{Pembahasan}

Karakteristik responden dari ketiga kelompok berdasarkan atas usia, BMI, status fisik ASA, hipertensi, diabetes melitus, asma, alergi, diagnosis, tindakan, lama operasi, fentanil durante telah homogen, sedangkan jenis kelamin pasien masih berbeda signifikan pada kelompok saline. Data jenis kelamin yang berbeda signifikan secara statistik pada kelompok saline mayoritas adalah laki-laki, sedangkan pada kelompok fentanil intravena dan levobupivakain jenis kelamin perempuan merupakan mayoritas masih dapat terjadi meskipun telah dilakukan randomisasi. Jenis kelamin sendiri tidak berpengaruh terhadap skala nyeri karena bukan merupakan faktor risiko terjadi nyeri pascaoperasi. Jenis kelamin dapat menjadi perancu pada hasil skala PONV karena termasuk dalam faktor risiko terjadi mual muntah pascaoperasi. ${ }^{10}$

Hasil penelitian menunjukkan perbedaan skala nyeri yang signifikan antara kelompok fentanil intravena, levobupivakain, dan saline pascaoperasi mastoidektomi. Pada kelompok fentanil intravena dan levobupivakain 
Tabel 3 Perbedaan Skala Nyeri antara Blok Pleksus Servikalis Superfisialis Levobupivakain dan Fentanil Intravena Pascaoperasi Mastoidektomi

\begin{tabular}{lccc}
\hline & Nyeri & \multicolumn{3}{c}{ Kelompok } & \multirow{2}{*}{ p } \\
\cline { 2 - 3 } & Fentanil & Levobupivakain & 0,542 \\
\hline NRS_2 & 8 & 9 & \\
Nyeri ringan & 2 & 1 & \\
Nyeri sedang & 0 & 0 & 0,146 \\
Nyeri berat & & 10 & \\
NRS_6 & 8 & 0 & \\
Nyeri ringan & 2 & 0 & 0,146 \\
Nyeri sedang & 0 & & \\
Nyeri berat & & 10 & \\
NRS_12 & 8 & 0 & \\
Nyeri ringan & 2 & 0 & \\
Nyeri sedang & 0 & 10 & \\
Nyeri berat & & 0 & \\
NRS_24 & 9 & 0 & \\
Nyeri ringan & 1 & & \\
Nyeri sedang & 0 & & \\
Nyeri berat & & & \\
\hline
\end{tabular}

Keterangan: Uji Mann-Whitney

memiliki efektivitas yang lebih baik sejak 2 jam hingga 24 jam pascaoperasi mastoidektomi. Distribusi kutaneus dari pleksus cervicalis adalah pada kulit bagian anterolateral leher oleh rami primer anterior dari C2-C4 yang muncul sebagai 4 saraf yang berbeda yaitu lesser occipital nerve, great auricular nerve, transverse cervical nerve, dan supraclavicular nerve.

Blok pleksus cervicalis superfisialis memberikan analgesia sensorik area postauricular dari scalp (lesser occipital), pinna eksternal, area auricular posterior, area temporoparietal scalp (greater auricular), bagian anterior leher (transverse cervical), dan area supraclavicular (supraclavicula). Blok nervus greater auricular telah berhasil digunakan untuk meredakan nyeri pasca operasi timpanomastoid dan otoplasty. Anakanak yang menjalani operasi timpanomastoid

Tabel 4 Perbedaan PONV antara Blok Pleksus Servikalis Superfisialis Levobupivakain dan Fentanil Intravena Pascaoperasi Mastoidektomi dan Saline

\begin{tabular}{|c|c|c|c|c|c|}
\hline \multirow{2}{*}{ PONV } & \multicolumn{3}{|c|}{ Kelompok } & \multirow{2}{*}{ Total } & \multirow{2}{*}{$\mathbf{p}$} \\
\hline & Fentanil & Levobupivakain & Saline & & \\
\hline Tidak mual & 0 & 4 & 2 & 6 & \multirow{4}{*}{0,180} \\
\hline Mual ringan & 6 & 4 & 5 & 15 & \\
\hline Mual berat & 0 & 0 & 1 & 1 & \\
\hline Muntah & 4 & 2 & 2 & 8 & \\
\hline
\end{tabular}

Keterangan: Uji Kruskal Wallis 
Tabel 5 Efek Samping dari Blok Pleksus Servikalis Superfisialis

\begin{tabular}{lcc}
\hline \multicolumn{1}{c}{ Kelompok } & Jumlah & Efek samping \\
\hline Blok dengan levobupivakain & 10 & - \\
Blok dengan $\mathrm{NaCl} 0,9 \%$ & 10 & - \\
\hline
\end{tabular}

memiliki predisposisi mual dan muntah yang lebih besar, yang dapat dikurangi dengan melakukan blok nervus greater auricular dan menghindari kebutuhan opioid perioperatif. Operasi timpanomastoid sendiri merupakan operasi dengan risiko PONV yang cukup tinggi. Blok pleksus cervicalis superfisialis bilateral dapat memberikan analgesia untuk operasi pada bagian anterior dari leher, seperti operasi tiroid, insisi trakeostomi (Gambar 1). ${ }^{11}$

Levobupivakain adalah (S)-enantiomer murni dari bupivakain. Diperkirakan karakteristik untuk blok saraf perifer sama dengan yang racemic mixture (bupivakain). Bloksaraf perifer dengan bupivakain seringkali memberikan durasi blok 4 sampai 12 jam bahkan sampai 24 jam. Hal ini menjadikan bupivakain obat yang sangat disukai untuk anestesia regional bila menginginkan durasi analgesia yang panjang. Dari penelitian dengan sukarelawan maupun hewan uji menunjukkan bahwa toksisitas kardiovaskular dan sistem saraf pusat dari levobupikain lebih rendah daripada bupivakain. ${ }^{12}$

Penelitian oleh Andrieu dkk. ${ }^{9}$ menunjukkan bahwa blok pleksus servikalis superfisialis bilateral dengan ropivakain dan klonidin efektif menurunkan kebutuhan analgetik pascaoperasi tiroid. Delapan puluh tujuh pasien dibagi secara acak ke dalam kelompok blok dengan saline, blok dengan ropivakain, dan blok menggunakan ropivakain ditambah klonidin. Anestesi umum dilakukan secara standar dengan monitor kedalaman anestesi menggunakan bispektral indeks (BIS) antara 40 sampai 60 . Setiap peningkatan denyut jantung atau tekanan arteri rata-rata 20\% selama intraoperasi diberikan sufentanil. Semua pasien mendapatkan asetaminofen 4 gram selama 24 jam pertama.

Penelitian yang serupa oleh Shih dkk. ${ }^{8}$ mengevaluasi efek analgetik dari blok pleksus servikalis superfisialis bilateral pada pasien yang menjalani operasi tiroidektomi. Pada penelitian ini mengikutsertakan 162 pasien sebagai sampel yang dibagi ke dalam tiga kelompok, yaitu blok dengan salin, blok dengan bupivakain, dan blok dengan levobupivakain. Anestesi umum dilakukan secara standar dengan cara monitor kedalaman anestesi menggunakan alat auditory evoked potential (AEP) dan arterial line autoregressive index (AAI). Agen inhalasi yang digunakan adalah desfluran dan dititrasi sesuai nilai AAI. Nyeri pascaoperasi selama 24 jam pada kelompok bupivakain dan levobupivakain lebih rendah bila dibanding dengan kelompok salin. ${ }^{8}$

Perbandingan langsung skala nyeri antara kelompok fentanil intravena dan levobupivakain menunjukkan tidak terdapat perbedaan yang bermakna secara statistik. Meskipun terdapat kecenderungan kelompok levobupivakain memiliki skala nyeri yang lebih baik, namun masih diperlukan penelitian lanjutan untuk meningkatkan kekuatan penelitian ini. Jadi, dapat dikatakan bahwa efek analgetik pascaoperasi dari blok pleksus servikalis superfisialis dengan levobupivakain sebanding dengan fentanil intravena.

Penelitian oleh Suresh dkk. ${ }^{13}$ menilai efek blok nervus aurikularis mayor dibanding dengan morfin intravena yang menjalani operasi timpanomastoid. Dari penelitian ini, 9 dari 20 pasien yang dilakukan blok nervus aurikularis mayor tidak pernah memperoleh opioid atau analgesik lain dalam 24 jam pascaoperasi. Meskipun terdapat 9 pasien juga dari 20 pasien yang membutuhkan anelgetik penyelamat saat di PACU, dibanding dengan 3 dari 20 pasien kelompok morfin intravena. Penelitian ini menyimpulkan bahwa kebutuhan analgetik penyelamat di ruang post anesthesia care unitsecara statistik tidak bermakna antara kelompok blok nervus aurikularis mayor dan 
kelompok morfin intravena $(\mathrm{p}=0,084)$. Hal ini menunjukkan bahwa blok nervus aurikularis mayor memiliki efek analgesia pascaoperasi yang sebanding dengan opioid morfin seperti yang terjadi pada penelitian penulis.

Penelitian yang lain yang dilakukan oleh Swain dkk. ${ }^{14}$ menunjukkan bahwa kombinasi blok nervus aurikularis mayor dan nervus aurikulo-temporalis dengan anestesi umum dapat menjadi teknik yang efektif, sederhana, dan dapat ditoleransi dengan baik untuk operasi mastoidektomi. Penelitian ini membandingkan efikasi blok saraf perifer terhadap penggunaan morfin intravena saat operasi mastoid. Total 50 pasien dilakukan randomisasi ke dalam dua kelompok, yaitu yang mendapatkan blok saraf (kelompok N) dan morfin intravena (kelompok M). Kelompok N menggunakan blok dengan bupivakain $0,25 \%$, sedangkan kelompok M menggunakan morfin intravena $0,1 \mathrm{mg} / \mathrm{kgBB}$. Hasilnya adalah nilai VAS selama 3 jam pascaoperasi dan kebutuhan analgetik penyelamat kelompok $\mathrm{N}$ lebih rendah signifikan secara statistik dibanding dengan kelompok M. ${ }^{15}$ Penelitian ini hanya menilai skala nyeri pada 3 jam pascaoperasi dan tidak memperhitungkan skala nyeri selama 24 jam. Dari penelitian kami pasien-pasien yang dilakukan blok dengan salin menunjukkan skala nyeri yang menetap sampai 24 jam pascaoperasi yang berarti nyeri pascaoperasi mastoidektomi dapat berlangsung sampai 24 jam.

Untuk kebutuhan fentanil selama operasi di antara ketiga kelompok tidak berbeda bermakna secara statistik. Kelompok levobupivakain cenderung mempergunakan dosis fentanil selama operasi lebih rendah bila dibanding dengan kelompok fentanil intravena dan saline $(229,5+41,0 ; 244,0+37,1$; $244,0+58,0 ; \mathrm{p}=0,076)$. Hasil penelitian ini berbeda dengan yang dilakukan oleh Andrieu dkk. ${ }^{9}$ Penyebabnya dalam penelitian tersebut menggunakan BIS untuk mengukur kedalaman anestesi, sedangkan pada penelitian penulis tidak. Dengan kedalaman anestesi yang seragam maka peningkatan denyut jantung sebagai respons dari nyeri intraoperatif lebih spesifik. Tanpa menggunakan BIS kedalaman anestesi tidak dapat dinilai secara seragam sehingga dalam penelitian ini peningkatan denyut jantung cenderung dianggap sebagai respons nyeri dan diberikan tambahan fentanil. Selain itu, penelitian tersebut juga mempergunakan fentanil yang dapat memperkuat efek analgesia dan memperlama durasi blok saraf perifer.

Penelitian Shih dkk. ${ }^{8}$ juga menyimpulkan blok pleksus servikalis superfisialis bilateral dapat menurunkan penggunaan opioid dan kebutuhan gas anestesi selama operasi. Dalam penelitian ini juga dilakukan penyeragaman dalam kedalaman anestesi dengan alat yang dapat mengukur secara objektif, yaitu auditory evoked potential (AEP) dan arterialline autoregression index (AAI). Monitor AAI adalah indikator yang akurat untuk menilai tingkat sedasi dan hilangnya kesadaran. Beberapa penelitian menunjukkan nilai AAI $20 \pm 5$, desfluran dapat menjaga efek anestesi yang adekuat.

Beberapa penelitian lain menunjukkan bahwa teknik anestesi regional dan lokal tidak dapat menurunkan kebutuhan analgetik pascaoperasi tiroid. ${ }^{16,17}$ Hasil ini mendasarkan pada penilaian VAS pascaoperasi dan juga kebutuhan analgetik. Kegagalan tindakan dan anestesi regional yang tidak efektif dapat menjadi penyebab. Teknik blok dengan pendekatan ultrasonografi dapat membantu meningkatkan keberhasilan blok pleksus servikalis superfisialis. ${ }^{18}$

Untuk skor PONV dari ketiga kelompok tidak terdapat perbedaan yang signifikan. Penggunaan levobupivakain memberikan skor paling baik terhadap PONV walaupun tidak signifikan secara statistik. Penelitian ini sejalan dengan hasil dari Shih dkk. ${ }^{8}$ dan Andrieu dkk. ${ }^{9}$ Pada penelitian Andrieu dkk. ${ }^{9}$ yang menggunakan kombinasi ropivakain dan klonidin yang terbukti menurunkan jumlah opioid selama operasi, tidak cukup untuk menurunkan insidens PONV. Beberapa faktor yang dapat memengaruhi kejadian PONV adalah penggunaan anestesi volatil dan nitrous oxide, tidak menggunakan profilaksis antiemetik, jumlah pasien dengan jenis kelamin perempuan, dan penggunaan nefopam 
sebagai analgetik penyelamat. Penelitian Andrieu dkk. ${ }^{9}$ dan Shih dkk. ${ }^{8}$ tersebut juga menganggap jumlah sampel yang digunakan untuk menurunkan insidens PONV masih kurang.

Beberapa faktor dalam penelitian ini yang dapat menjadi penyebab kejadian PONV adalah jenis kelamin perempuan. Distribusi jenis kelamin perempuan lebih banyak pada kelompok fentanil dan juga levobupivakain. Meskipun bila dibandingkan secara statistik kejadian PONV tidak bermakna signifikan, namun pada kelompok fentanil insidens PONV berat lebih tinggi karena pasien mengalami muntah mencapai 4 orang dari 10 pasien. Bila menilai faktor risiko PONV dengan skor dari Apfel dkk. ${ }^{10}$ yang terdiri atas jenis kelamin perempuan, tidak merokok, riwayat mabuk perjalanan,danpenggunaanopioid perioperatif maka kelompok pasien yang akan menjalani mastoidektomi sebagian merupakan pasien dengan risiko tinggi PONV. Ditambah faktorfaktor risiko lain yang terbukti meningkatkan risiko PONV, yaitu usia muda, penggunaan anestesi inhalasi, dan durasi anestesi yang lama membuat kelompok pasien ini sangat berisiko. Menurut pedoman dari Society for Ambulatory Anesthesiology pasien dengan risiko tinggi PONV membutuhkan kombinasi 2 atau lebih antiemetik profilaksis. ${ }^{10,19}$ Pada penelitian ini antiemetik profilaksis hanya menggunakan satu jenis obat, yaitu metoklopramid. Jumlah opioid selama operasi yang tidak berbeda secara signifikan antara tiap-tiap kelompok juga dapat menjadi penyebab.

Tindakan pada blok pleksus servikalis superfisialis adalah tindakan yang aman untuk dilakukan terbukti dari penelitian ini tidak ada kejadian efek samping dari 20 tindakan blok pleksus servikalis superfisialis. Beberapa kasus melaporkan efek samping lebih sering terjadi bila menggunakan agen anestesi lokal dengan konsentrasi lebih tinggi (bupivakain $0,5 \%)$, volume lebih banyak ( $>10 \mathrm{~mL}$ ), dan insersi jarum yang terlalu dalam sampai menembus otot-otot leher. ${ }^{15}$

Keterbatasan penelitian ini adalah tidak memakai alat pengukur kedalaman anestesi sehingga penyeragaman tingkat anestesi di antara kelompok tidak dapat terukur secara lebih objektif, distribusi jenis kelamin yang kurang merata di antara kelompok yang mungkin berpengaruh dalam insiden PONV, dan jumlah sampel yang relatif sedikit. Untuk memperbaiki distribusi yang kurang merata dapat dilakukan dengan menggunakan teknik randomisasi dengan komputer untuk penelitian selanjutnya.

\section{Simpulan}

Terdapat perbedaan skala nyeri antara blok pleksus servikalis superfisialis levobupivakain, fentanil intravena, dan saline pascaoperasi mastoidektomi. Perbandingan yang langsung levobupivakain dengan fentanil intravena tidak berbeda. Jadi, blok pleksus servikalis superfisialis dapat digunakan sebagai analgetik alternatif yang sebanding dengan fentanil intravena pascaoperasi mastoidektomi.

Kebutuhan opioid selama operasi dan kejadian PONV antara ketiga kelompok tidak berbeda. Tindakan blok pleksus servikalis superfisialis itu merupakan tindakan yang sederhana dan aman digunakan bila dilakukan dengan hati-hati dan sesuai dengan prosedur.

\section{Daftar Pustaka}

1. Sarantopoulos C. Pain pathways and mechanisms. Dalam: Abram SE, penyunting. Pain medicine: the requisites in anesthesiology. Philadelphia: Mosby Elsevier; 2006. hlm. 1-3.

2. Jaffe R, Schmiesing C, Golianu B. Anesthesiologists manual of surgical procedures. Edisi ke-5. Philadelphia: Lippincott Williams \& Wilkins; 2014.

3. Nemati S, Okhovvat SA, Naghavi E, Shakiba $\mathrm{M}$, Mikaeeli S. Relative frequency of chronic postoperative pain in patients operated for chronic otitis media. Euro Archi OtoRhino-Laryngol. 2013;271(8):2139-43.

4. Chou R, Gordon DB, de Leon-Casasola OA, Rosenberg JM, Bickler S, Brennan $\mathrm{T}$, dkk. Management of postoperative pain: a clinical practice guideline from the american pain society, the american 
society of regional anesthesia and pain medicine, and the american society of anesthesiologists' committee on regional anesthesia. Executive Committee, and Administrative Council. J Pain. 2016;17(2):131-57.

5. Cadavid-Puentesa A, Guerrerob FJB, Salazar OG, Zapataa FM, Henaoa JO, Sierraa JR, dkk. Comparison of the effectiveness of fentanil versus morphine for severe postoperative pain management. A randomized, double blind, clinical trial. Colomb J Anestesiol. 2017;45(2):100-7.

6. Moghul N, Doyle DJ. Common otolaryngology procedures. Dalam: Vacanti CA, penyunting. Essential clinical anesthesia. Cambridge: Cambridge University Press; 2011. hlm. 362-3.

7. Suresh S, Jagannathan N. Somatic blockade of the head and neck. Dalam: Cousins MJ, penyunting. Cousins \& Bridenbaugh's neural blockade in clinical anesthesia and pain medicine. Edisi ke-4. Philadelphia: Lippincott Williams \& Wilkins, a Wolters Kluwer Business; 2009.

8. Shih M, Duh Q, Hsieh C, Liu Y, Lu C, Wong $\mathrm{C}$, dkk. Bilateral superficial cervical plexus block combined with general anesthesia administered in thyroid operations. World J Surg. 2010;34(10):2338-43.

9. Andrieu G, Amrouni H, Robin E, Carnaille B, Wattier JM, Pattou F, dkk. Analgesic efficacy of bilateral superficial cervical plexus block administered before thyroid surgery under general anaesthesia. $\mathrm{Br} \mathrm{J}$ Anaesth. 2007;99(4):561-6.

10. Apfel C, Heidrich F, Jukar-Rao S, Jalota L, Hornuss C, Whelan R, dkk. Evidence-based analysis of risk factors for postoperative nausea and vomiting. $\mathrm{Br} \mathrm{J}$ Anaesth. 2012;109(5):742-53.

11. Suresh S, Jagannathan N. Somatic blockade of the head and neck. Dalam: M.J. Cousins penyunting. Cousins \& Bridenbaugh's Neural Blockade in Clinical Anesthesia and Pain Medicine fourth edition. Lippincott
Williams \& Wilkins, a Wolters Kluwer business, Philadelphia. 2009;17:420-2.

12. Bernards, CM. Local anesthetics. Dalam: MF Mulroy, penyunting. A practical approach to regional anesthesia. Edisi ke4. Philadelphia: Wolter Kluwer-Lippincott Williams \& Wilkins. 2009;1:1-10.

13. Suresh S, Barcelona SL, Young NM, Seligman I, Heffner CL, Cote CJ. Postoperative pain relieve in children undergoing tympanomastoid surgery: is a regional block better than opioids?. Anesth Analg. 2002;94:859-62.

14. Swain SK, Pradhan C, Mohanty S, Sahu MC. Comparative study between selective nerve blocks and the intravenous opioids in mastoid surgery. Egyptian J Ear Nose Throat Allied Sci. 2016;18(2017):121-5.

15. Hannadige $\mathrm{H}$, Somaweera S. A complication of superficial cervical plexus block used for thyroidectomy. Sri Lankan J Anaesthesiol. 2015;23(2):77-9.

16. Eti Z, Irmak P, Gulluoglu BM, Manukyan MN, Gogus FY. Does bilateral superficial cervical plexus block decrease analgesic requirement after thyroid surgery?. Anesth Analg. 2006;102:1174-6.

17. Herbland A, Cantini O, Reynier P, Valat P, Jougon J, Arimone Y, dkk. The bilateral superficial cervical plexus block with $0.75 \%$ ropivacaine administrated before or after surgery dose not prevent postoperative pain after total thyroidectomy. Reg Anesth Pain Med. 2006;31:31-9.

18. Senapathi TGA, Widnyana IMG, Aribawa IGNM, Wiryana M, Sinardja IK, Nada IKW, dkk. Ultrasound-guided bilateral superficial cervical plexus block is more effective than landmark technique for reducing pain from thyroidectomy. J Pain Res. 2017;10:1619-22.

19. Gan TJ, Diemunsch, Habib AS, Kovac A, Kranke P, Meyer TA, dkk. Consensus guidelines for the management of postoperative nausea and vomiting. Anesth Analg. 2014;118:85-113. 